\title{
Antifungal Aromadendrane Sesquiterpenoids from the Leaves of Xylopia brasiliensis
}

\author{
Isabel C. Moreira ${ }^{a}$,João Henrique G. Lago ${ }^{*, a}$, Maria Cláudia M. Young and Nídia F. Roque ${ }^{a, c}$ \\ ${ }^{a}$ Instituto de Química, Universidade de São Paulo, CP 26077, 05599-970 São Paulo - SP, Brazil \\ ${ }^{b}$ Seção de Fisiologia e Bioquímica de Plantas, Instituto de Botânica, CP 4005, 01061-970 São Paulo - SP, Brazil \\ ${ }^{c}$ Instituto de Química, Universidade Federal da Bahia, 40170-290 Salvador - BA, Brazil
}

\begin{abstract}
Um novo sesquiterpeno, aromadendrano- $4 \beta, 10 \alpha, 15$-triol, foi isolado das folhas de Xylopia brasiliensis Spreng (Annonaceae), juntamente com quatro derivados de esqueleto aromadendrano e três esteróides. As estruturas dos metabólitos foram definidas por meio da análise dos respectivos espectros de RMN, incluindo experimentos bidimensionais, além de espectrometria de massas. Os sesquiterpenos aromadendranos diidroxilados apresentaram atividade antifúngica frente a Cladosporium cladosporioides.
\end{abstract}

A new sesquiterpenoid, aromadendrane- $4 \beta, 10 \alpha, 15$-triol, was isolated from the leaves of Xylopia brasiliensis Spreng (Annonaceae), together with four known aromadendrane derivatives and three steroids. The structures of these compounds were defined by analysis of their NMR spectral data, including bidimensional analysis, and mass spectrometry. The isolated aromadendranediol derivatives showed antifungal activity against Cladosporium cladosporioides.

Keywords: Xylopia brasiliensis, aromadendrane sesquiterpenoids, antifungal activity

\section{Introduction}

The genus Xylopia (Annonaceae) comprises about 160 species with occurrence in South and Central America, Africa and Asia. ${ }^{1,2}$ Aproximatelly 25 species of Xylopia were identified in Brazil, mainly in Amazonia. ${ }^{2}$ These species produce a wide variety of metabolites including alkaloids, amides, lignoids, acetogenins and terpenoids..$^{3-7}$ $X$. brasiliensis, a very large tree distributed in Southeastern Brazil, is known as "pindaíba", "pindaubuna" and "bindaíba" and has been used in the folk medicine as a sedative and analgesic. Previous investigations of the chemical constituents of this plant resulted in the isolation of diterpenoids and aporphine alkaloids from the fruits and stem bark, respectively. ${ }^{8,9}$ In addition of our studies on $X$. brasiliensis, we describe herein the isolation and identification of five aromadendrane sesquiterpenoids, including a new derivative, besides three known steroids. All the sesquiterpenoids were submitted to antifungal assay against Cladosporium cladosporioides and the dihydroxylated derivatives showed pronounced activity.

* e-mail: joaolago@iq.usp.br

\section{Results and Discussion}

The $\mathrm{CH}_{2} \mathrm{Cl}_{2}$ extract from the leaves was subjected to repeated chromatography on silica gel and on Sephadex LH-20 columns. Spectrometric analysis of the fractions resulted in the identification of five aromadendrane sesquiterpenoids: spathulenol (1), aromadendrane- $4 \alpha, 10 \beta$ diol (2), aromadendrane- $4 \alpha, 10 \alpha$-diol (3) and alloaromadendrane- $4 \beta, 10 \alpha$-diol (4), including a new derivative, which was characterized as aromadendrane- $4 \beta, 10 \alpha, 15$ triol (5) and three steroids: sitosterol (6), stigmasterol (7) and sitosterol-3- $\beta$-D-galactoside (8). To our knowledge, this is the first report of the occurrence of $\mathbf{2 , 3}$ and $\mathbf{4}$ in Xylopia genus.

The sesquiterpenoids 1, 2, 3 and $\mathbf{4}$ and the steroids 6, 7 and $\mathbf{8}$ were identified by analysis of their ${ }^{1} \mathrm{H}$ and ${ }^{13} \mathrm{C}$ NMR spectroscopic data and comparison with literature data. ${ }^{10-14}$

The ${ }^{13} \mathrm{C}$ NMR spectrum of $\mathbf{5}$ displayed fifteen signals, three of which are of carbinolic carbon atoms $[\delta 80.5$ (C), $75.8(\mathrm{C})$ and $\left.62.1\left(\mathrm{CH}_{2}\right)\right]$. These data, associated to molecular ion peak at $255 \mathrm{Da}[\mathrm{M}+\mathrm{H}]^{+}$in ESIMS, suggested the structure of a trihydroxysesquiterpenoid with molecular formula $\mathrm{C}_{15} \mathrm{H}_{26} \mathrm{O}_{3}$. The ${ }^{1} \mathrm{H}$ NMR spectrum of $\mathbf{5}$ showed absorptions of a cyclopropane ring at $\delta 0.41(1 \mathrm{H}$, 


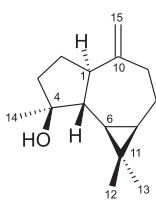

1

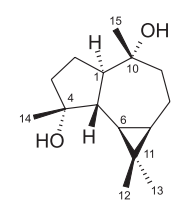

2

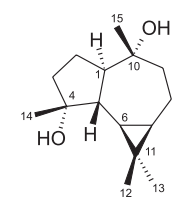

3

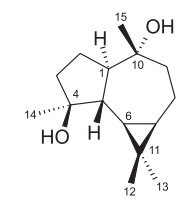

$3 a$

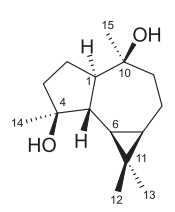

$3 \mathbf{b}$

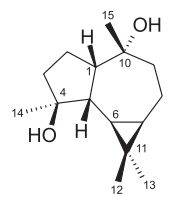

4

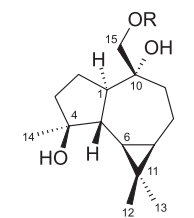

$5 \quad \mathrm{R}=\mathrm{H}$ $5-\mathrm{Ac} \mathrm{R}=\mathrm{C}(\mathrm{O}) \mathrm{CH}_{3}$

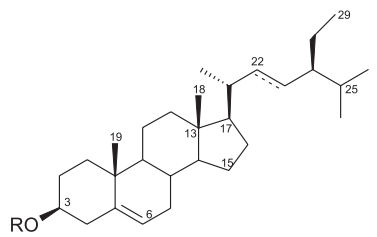

$6 \mathrm{R}=\mathrm{H}, 22$,23-dihydro

$7 \mathrm{R}=\mathrm{H}, \Delta^{22}$ $8 \mathrm{R}=\overbrace{\mathrm{OH}}^{\mathrm{OH}} \widehat{\mathrm{OH}}, 22,23$-dihydro dd, J 10.8 and $9.6 \mathrm{~Hz})$ and at $\delta 0.65(1 \mathrm{H}, \mathrm{m})$, which are a characteristic feature of the aromadendrane skeleton. ${ }^{11}$ This spectrum also showed one singlet at $\delta 1.02(6 \mathrm{H})$, assigned to a gem-dimethyl group linked to a quaternary carbon, and one singlet at $\delta 1.25(3 \mathrm{H})$ assigned to one methyl group joined to a tertiary carbinolic carbon. The data of $\mathbf{5}$, compared with those of related compounds aromadendrane- $4 \alpha, 10 \alpha$-diol (3) and aromadendrane$4 \beta, 10 \alpha$-diol (3a), ${ }^{12}$ indicated that the hydroxyl groups at C-4 and C-10 have $\beta$ and $\alpha$ orientation, respectively. ${ }^{11}$ The presence of an $\mathrm{AB}$ system at $\delta 3.66(1 \mathrm{H}, J 11.3 \mathrm{~Hz})$ and at $\delta 3.73(1 \mathrm{H}, J 11.3 \mathrm{~Hz})$ suggested the presence of a primary alcohol in 5. Accordingly the signal at $\delta 62.1$ in the ${ }^{13} \mathrm{C}$ NMR spectra (BBD and DEPT $135^{\circ}$ ) was assigned to the oxygenated methylenic group. The third hydroxyl group was thus positioned at C-15 shielding C-9 chemical shift by a $\gamma$-gauche effect of $5 \mathrm{ppm}$, when compared with aromadendrane- $4 \beta, 10 \beta$-diol (3b). ${ }^{11}$ This proposal was confirmed by $\mathrm{HMBC}$ spectrum, which showed a long range coupling between C-15/H-1, C-15/H-9 and C-10/H-15. The positioning of the hydroxyl group at $\mathrm{C}-15$ was also confirmed by analysis of ${ }^{13} \mathrm{C}$ NMR data of the monoacetylated derivative (5-Ac), which showed a deshielding effect of $2.7 \mathrm{ppm}$ of $\mathrm{C}-15$ and a shielding effect of $0.8 \mathrm{ppm}$ to $\mathrm{C}-10$, due to $\beta$ and $\gamma$ effects respectively, when compared with those of $\mathbf{5}$. Therefore, the structure of 5 was defined as aromadendrane- $4 \beta, 10 \alpha, 15$-triol.

The antifungal activity of sesquiterpenoids $2, \mathbf{3}, \mathbf{4}$ and
5 was evaluated by means of direct bioautography on TLC plate. The aromadendrane derivatives 2, 3 and $\mathbf{4}$ showed antifungal activity against $C$. cladosporioides and their minimun amount required to inhibit growth of this fungus were detemined as $5 \mu \mathrm{g}$. Nystatin $(5 \mu \mathrm{g})$ and miconazole (1 $\mu \mathrm{g})$ were used as positive controls.

\section{Experimental}

\section{General}

NMR spectra were recorded at 75 and $125 \mathrm{MHz}$ to ${ }^{13} \mathrm{C}$ and 300 and $500 \mathrm{MHz}$ for ${ }^{1} \mathrm{H}$ (Bruker DPX-300 and DRX500 spectrometers, respectively). The spectra were recorded in $\mathrm{CDCl}_{3}$ (Aldrich); $\delta$ values were expressed in ppm relative to the residual signal of $\mathrm{CHCl}_{3}$ in $\mathrm{CDCl}_{3}$; IR spectra were obtained using $\mathrm{KBr}$ pellets in a Perkin-Elmer Infrared Spectrometer model 1750; ESIMS were obtained in a Platform II-Micromass Spectrometer (quadrupole). EIMS were obtained with a $70 \mathrm{eV}$ INCOS 50 Finnigan-Matquadrupole mass spectrometer; silica gel 60 (Merck) and Sephadex LH-20 (Pharmacia) were used for column chromatography $(63-200 \mu \mathrm{m})$; pre-coated aluminium silica gel plates $\mathrm{PF}_{254}$ (Merck) were used for TLC analysis.

\section{Plant material}

The leaves of $X$. brasiliensis were collected at the Instituto de Botânica on February, 1998, São Paulo, Brazil. A voucher specimen (YOUNG10) is deposited at the herbarium of Instituto de Botânica (SMA-SP).

\section{Extraction and isolation of the constituents}

The air-dried and powdered leaves (900 g) were extracted with $\mathrm{CH}_{2} \mathrm{Cl}_{2}$. After removal of the solvent by evaporation under reduced pressure, a part of the crude extract (18 g) was chromatographed on a silica gel column, eluting with hexane $/ \mathrm{CH}_{2} \mathrm{Cl}_{2} / \mathrm{MeOH}$ in gradient mixtures to give 130 fractions (125 mL each). Fractions were combined based on their TLC pattern to yield fractions designed as X-1/X-17. Fraction X-4 (280 mg) was purified by column chromatography over silica gel with $\mathrm{CH}_{2} \mathrm{Cl}_{2}$ / $\mathrm{MeOH}$ (98:2) to yield $21 \mathrm{mg}$ of $\mathbf{1}$. Fraction X-7 (1 g) was applied to a silica gel column, eluted with $\mathrm{CH}_{2} \mathrm{Cl}_{2} / \mathrm{MeOH}$ (9:1) to yield a mixture of 6 and 7 (43 mg). Fraction X-13 (320 mg) was subjected to Sephadex LH-20 (30 g - 2x30 $\mathrm{cm})$ using a gradient elution system [hexane $/ \mathrm{CH}_{2} \mathrm{Cl}_{2}$ (1:4) followed by $\mathrm{CH}_{2} \mathrm{Cl}_{2} / \mathrm{Me}_{2} \mathrm{CO}$ (3:2) and (1:4)] to give four subfractions. Sesquiterpenes 2 (10 mg), 3 (12 mg) and 4 ( $9 \mathrm{mg}$ ) were purified after $\mathrm{CC}$ on silica gel of the subfraction 
Table 1. ${ }^{1} \mathrm{H}$ and ${ }^{13} \mathrm{C}$ NMR data and long-range correlations observed in the $\mathrm{HMBC}$ for sesquiterpenoid $\mathbf{5}$ and $\mathbf{5}-\mathbf{A c}(500$ and $125 \mathrm{MHz}, \delta, \mathrm{CDCl}$ )

\begin{tabular}{|c|c|c|c|c|c|c|}
\hline \multirow[b]{2}{*}{ position } & \multicolumn{3}{|c|}{5} & \multicolumn{3}{|c|}{$5-\mathrm{Ac}$} \\
\hline & $\delta_{\mathrm{H}}($ multiplicity; $\mathrm{J} / \mathrm{Hz})$ & $\delta_{\mathrm{C}}$ & HMBC & $\delta_{\mathrm{H}}($ multiplicity; $\mathrm{J} / \mathrm{Hz})$ & $\delta_{\mathrm{C}}$ & HMBC \\
\hline 1 & $2.07(\mathrm{t})$ & 55.4 & H-2; H-5; H-9; H-15 & $2.01(\mathrm{t})$ & 55.0 & H-9; H-5 \\
\hline 2 & $1.65(\mathrm{~m}) ; 1.79(\mathrm{~m})$ & 23.9 & $\mathrm{H}-1 ; \mathrm{H}-3$ & $1.22(\mathrm{~m}) ; 1.55(\mathrm{~m})$ & 23.7 & \\
\hline 3 & $1.52(\mathrm{~m}) ; 1.65(\mathrm{~m})$ & 41.2 & H-2; H-14 & $1.55(\mathrm{~m}) ; 1.62(\mathrm{~m})$ & 41.2 & \\
\hline 4 & - & 80.5 & H-3; H-5; H-6; H-14 & - & 80.2 & H-6; H-14; H-3 \\
\hline 5 & $1.22(\mathrm{t} ; 10.7)$ & 47.1 & H-1; H-3; H-14 & $1.25(\mathrm{t})$ & 47.4 & H-14 \\
\hline 6 & $0.41(\mathrm{dd} ; 10.8,9.6)$ & 29.2 & H-1; H-5; H-8 & $0.43(\mathrm{dd} ; 10.8,9.5)$ & 28.7 & $\mathrm{H}-8$ \\
\hline 7 & $0.65(\mathrm{~m})$ & 26.3 & H-6; H-8; H-9; H-12; H-13 & $0.65(\mathrm{~m})$ & 26.5 & \\
\hline 8 & $0.90(\mathrm{~m}) ; 1.72(\mathrm{~m})$ & 19.7 & H-5; H-9; H-15 & $0.90(\mathrm{~m}) ; 1.75(\mathrm{~m})$ & 19.6 & \\
\hline 9 & $1.30(\mathrm{~m}) ; 2.05(\mathrm{~m})$ & 37.9 & H-1; H-8; H-15 & $1.40(\mathrm{~m}) ; 1.95(\mathrm{~m})$ & 38.3 & \\
\hline 10 & - & 75.8 & H-1; H-5; H-8; H-9; H-15 & - & 75.0 & $\mathrm{H}-9$ \\
\hline 11 & - & 19.9 & H-6; H-12; H-13 & - & 20.0 & \\
\hline 12 & $1.02(\mathrm{~s})$ & 28.6 & H-6; H-7; H-13 & $1.02(\mathrm{~s})$ & 28.6 & H-6; H-7 \\
\hline 13 & $1.02(\mathrm{~s})$ & 16.4 & H-8; H-12 & $1.02(\mathrm{~s})$ & 16.4 & $\mathrm{H}-8 ; \mathrm{H}-12$ \\
\hline 14 & $1.25(\mathrm{~s})$ & 24.5 & H-5 & $1.20(\mathrm{~s})$ & 24.5 & \\
\hline 15 & $3.66(\mathrm{~d} ; 11.3) 3.73(\mathrm{~d} ; 11.3)$ & 62.1 & H-9; H-1 & $4.22(\mathrm{~d} ; 11.8) 4.29(\mathrm{~d} ; 11.8)$ & 64.8 & H-9 \\
\hline $\mathrm{C}(\mathrm{O})$ & - & - & - & - & 171.3 & $\mathrm{H}-15 ; \mathrm{C}(\mathrm{O}) \mathrm{CH}_{3}$ \\
\hline $\mathrm{CH}_{3}$ & - & - & - & $2.15(\mathrm{~s})$ & 21.0 & H-15 \\
\hline
\end{tabular}

$2(80 \mathrm{mg})$, using increasing amount of EtOAc in hexane as eluent. Fraction X-16 was composed, mainly, by steroid 8 (20 mg). Fraction X-17 (120 mg) was aplied to a silica gel column, eluted with $\mathrm{CH}_{2} \mathrm{Cl}_{2} / \mathrm{MeOH}(8: 2)$, to afford 5 (30 mg).

\section{Aromadendrane-4 $\beta, 10 \alpha, 15$-triol (5)}

Colourless oil; IR (KBr) $v_{\text {max }} / \mathrm{cm}^{-1}: 3605,2941,2873$, 1461, 1375, 1070, 1026, 891. EIMS (70 eV): 254(not observed), 236(18), 218(22), 203(29), 185(29), 175(72), 160(49), 147(87), 135(64), 119(87), 105(96), 91(100), 79(79), 69(71), 55(93); ESIMS: 255 [M+H]; NMR data $\left({ }^{1} \mathrm{H},{ }^{13} \mathrm{C}, \mathrm{HMQC}, \mathrm{HMBC}\right)$ are given in Table 1.

\section{5-Acetoxy-aromadendrane-4 $\beta, 10 \alpha$-diol (5-Ac)}

Obtained by treatment of $\mathbf{5}(10 \mathrm{mg})$ with $\mathrm{Ac}_{2} \mathrm{O}(1.0 \mathrm{~mL})$ and pyridine $(1.0 \mathrm{~mL})$. The usual work-up, followed by silica gel chromatography of the crude product furnished 5-Ac $(10 \mathrm{mg})$ as a colourless oil. NMR data $\left({ }^{1} \mathrm{H},{ }^{13} \mathrm{C}, \mathrm{HMBC}\right)$ are given in Table 1.

\section{Antifungal assay}

Dilutions containing 100, 50, 25, 10, 5, 1 and $0.1 \mu \mathrm{g}$ of pure compounds were applied on a pre-coated TLC plate. The plate was developed with hexane/EtOAc (7:3). The chromatogram was sprayed with a spore suspension of $C$. cladosporioides in glucose and salt solution and was incubated for $72 \mathrm{~h}$ in darkness in a moistened chamber at
Table 2. ${ }^{13} \mathrm{C}$ NMR data to sesquiterpenes $\mathbf{2}, \mathbf{3}, \mathbf{3 a}, \mathbf{3 b}$ and 4 (75 MHz, $\left.\delta, \mathrm{CDCl}_{3}\right)$

\begin{tabular}{cccccc}
\hline position & $\mathbf{2}$ & $\mathbf{3}$ & $\mathbf{3 a}$ & $\mathbf{3 b}$ & $\mathbf{4}$ \\
\hline 1 & 52.5 & 54.5 & 56.2 & 56.4 & 49.6 \\
2 & 23.7 & 23.7 & 23.7 & 24.3 & 23.8 \\
3 & 39.6 & 40.3 & 41.0 & 41.4 & 38.2 \\
4 & 80.5 & 80.1 & 80.1 & 80.3 & 83.1 \\
5 & 45.8 & 47.5 & 48.2 & 47.2 & 48.5 \\
6 & 24.9 & 25.0 & 28.3 & 30.1 & 26.4 \\
7 & 27.0 & 26.2 & 26.5 & 26.9 & 24.6 \\
8 & 19.1 & 20.3 & 20.0 & 19.2 & 20.4 \\
9 & 42.4 & 44.2 & 44.3 & 42.8 & 39.5 \\
10 & 72.8 & 75.3 & 74.8 & 71.8 & 74.5 \\
11 & 20.1 & 18.9 & 19.4 & 20.9 & 20.1 \\
12 & 29.0 & 28.8 & 28.5 & 28.7 & 28.6 \\
13 & 16.4 & 16.4 & 16.3 & 16.4 & 15.3 \\
14 & 25.8 & 25.6 & 24.3 & 25.1 & 24.2 \\
15 & 31.2 & 19.7 & 20.0 & 30.5 & 30.6 \\
\hline
\end{tabular}

$25{ }^{\circ} \mathrm{C} .{ }^{15}$ Clear inhibition zones appeared against a dark blackground, indicating the minimal amount required for inhibition of fungal growth on TLC plate. Nystatin $(5 \mu \mathrm{g})$ and miconazole $(1 \mu \mathrm{g})$ were used as positive controls. The microorganism used in the antifungal assay, $C$. cladosporioides (Pemzig) SPC 491, has been maintained at Instituto de Botânica (SP).

\section{Acknowledgments}

This work was supported by FAPESP (J.H.G.L., I.C.M. and M.C.M.Y.) and CNPq (N.F.R.). 


\section{References}

1. Hocquemiller, R.; Cavè, A.; Rahariolalao, A.; J. Nat. Prod. 1981, 44, 551.

2. Takhtajan, A.; Floristic Regions of the World, Los Angeles, Univ. California Press: Los Angeles, 1986.

3. Martins, D.; Alvarenga, M.A.; Roque, N.F.; Felício, J.D.; Quim. Nova 1995, 18, 14.

4. Lajide, L.; Escoubas, P.; Mizutani, J.; Phytochemistry 1995, $40,1105$.

5. Wahl, A.; Roblot, F.; Cavè, A.; J. Nat. Prod. 1995, 58, 786.

6. Colman-Saizarbitoria, T.; Gu, Z.M.; Zhao, G.X.; J. Nat. Prod. 1995, 58, 532 .

7. Takahashi, J.A.; Boaventura, M.A.D.; Bayma, J.C.; Oliveira, A.B.; Phytochemistry 1995, 40, 607.

8. Vilegas, W.; Alvarenga, M.A.; Roque, N.F.; Rev. Latinoamer. Quim. 1989, 20, 98.
9. Casa Grande, C.; Merotti, G.; Il Farm. Ed. Sci. 1970, 25, 799.

10. Iwabushi, H.; Yoshikura, M.; Kamisako, W.; Chem. Pharm. Bull. 1989, 37, 509.

11. Goldsbym, G.; Burke, A.B.; Phytochemistry 1987, 26, 1059.

12. Gijsen, H.J.M.; Wijnberg, J.B.P.A.; Stork, G.A.; DeGroot, A.; Tetrahedron 1992, 48, 2465.

13. Ahmad, V.U.; Aliya, R.; Perveern, S.; Shameel, M.; Phytochemistry 1992, 31, 1429.

14. Osman, A.M.; Younes, M.E.; Moktar, A.; Phytochemistry 1975, $14,829$.

15. Homans, A.L.; Fuchs, A.; J. Chromatogr. 1970, 327.

Received: August 6, 2001

Published on the web: June 2, 2003

FAPESP helped in meeting the publication costs of this article. 